\title{
Theory, Practice, and Analysis of Indonesia's Foreign Policy
}

\author{
Fadlan Muzakki \\ Fellowship Graduate in International Relations \\ at Zhejiang University, Hangzhou - Zhejiang, China \\ Email: fadlanmuzakki@zju.edu.cn
}

\begin{abstract}
Indonesian foreign policy is considered as a uniqe and rare policy. This is because the main focus of Indonesian foreign policy is Free and Active. For country like Indonesia which had just got independence in 1945, the country is considered as a country with a pioneer foreign policy to stand in a non-block. Therefore, Indonesia was quite popular with non-block movement and Bandung Conference in the Cold War Period. This paper discusses Indonesian foreign policy and match its policy with underlying theory of Foreign Policies: Realism, Idealism, and Constructivism. Moreover, this essay also analyses Indonesian Foreign Policy through Middle Power Concept. Additionally, this essay also explains the practices of Indonesian Foreign Policy in current years, especially under Joko Widodo's Administration. Last but not least, the author also reveals Indonesian foreign policy and its relations to media, society or public opinion.
\end{abstract}

Key Words: Indonesia, Foreign Policy, Theory, Realism, Idealism, Constuctuvism

\section{BACKGROUND}

Indonesia has just got independence after World War Two in 1945. Before the independence, the country was colonialized by Dutch for around 3.5 centuries and Japan for three and a half years. The West and the East were engaged in domestic politics and governance for a great number of years before Indonesian independence. Nevertheless, getting independence in 1945 did not mean that Indonesia is free from the colony. Dutch colonial seemed not really sincere to leave Indonesia. It was proved by the event which was commonly known as Operation Crow or second Dutch Military Aggression, this had just happened several years after the independence.

Therefore, Indonesian foreign policy can be said as a policy which leads to be getting freedom for its citizen. It is also said to active in a great number of international forums. However, this is confusing because Indonesian foreign policy is sometime 
considered as realism, idealism, and constructivism. Indonesian foreign policy in current world also considered as middle power concept.

Thus, this essay will explains the theory of foreign policy which can define Indonesian foreign policy event by event and also tells the current Indonesian foreign policy. Furthermore, my concept of how media and society involve in foreign policy is also explained in this essay. To make this essay more interesting, there are several research questions which are explained bellow:

\section{RESEARCH QUESTIONS}

To get a fully grasp of theory and analyses in Indonesian foreign policy, this paper has raised several research questions with the purpose of explaining theories and practices in Indonesian foreign policy comprehensively. The research questions are mentioned below:

- What is the theory of foreign policy much suited to explain Indonesian foreign policy?

- What is the meaning of Free and Active in Indonesian foreign policy?

- How is the current Indonesian foreign policy?

- How do media and society influence foreign policy in Indonesia?

\section{LITERATURE REVIEW}

In order to be able to answer the research questions, it is needed to understand different theories in Foreign Policy. There are three fundamental theories which are usually used by international relations scholars. These are realism, idealism, and constructivism. However, there are still several theories and concepts to get a fully grasp of foreign policy and its analysis. For example, geopolitics theory is sometime used by international relations scholars to analyses foreign policy from a country. Another example can be seen from middle power concept which is also sometime used by scholars to analyses foreign policy from a country. Nonetheless, this essay will focus the construction of three fundamental theories in foreign policy.

First of all, realism theory which is the fundamental theory of international relations is often used to analyse foreign policy. It has been broadly known that realism is recognizing countries as main actors and key role in political arena. Realism consider non-state actors much less compared to states. Additionally, realism also considers that international system is anarchic because the theory sees no supranational authority which is able to enforce rules over countries. Moreover, this theory also recognizes that International System is rational asinmuch as the actions from countries can maximize its own national interest. In other words, the main reason countries do something is to strengthen its national interest. Therefore, it can be 
stated that realism recognizes power as a main tool to obtaining and maximizing national interest.

A great number of cases can be seen to prove that countries are using realism perspective to design its foreign policy. The cases in world war and in cold war can be the examples of the realism foreign policy. Those cases are strengthened by Smith which state that foreign policy in a country is placing its national interest and it security above everything such as ideology of the country, ethnics, value, and morality in the country (Smith, 2011). Another example can be seen from Americans agreeing that the goal of foreign policy should be got or obtained whatever the condition is. Moreover, it is undoubtable that means of every country are national interest. Moreover, in realist perspective, Foreign Policy can be defined as a tool for reaching national interest (Policy, 2009).

Foreign Policy in idealism perspective recognized that a country has goal of internal political condition to reach its foreign policy. In this term, idealism scholars recognize that ending poverty inside the country should be cooperated by coping with poverty abroad. Moreover, th US President Woodrow Wilson is considered as the first person of idealism in foreign policy. Wilson's idea in 1919's Paris Peace Conference was a kind of idealism of foreign policy from the US. The willingness to build peace after World War 1 and building international institution to stabilize the peace was a result of Wilson speech at the Peace Conference. That is why, Foreign Policy in idealism perspective is oftely associated with institution builder or a policy which is correlated with peace and international institution. Beside the idealist perspectives scholars posit that foreign policy should reflect at least the ethical and moral as well as philosopical values of the country (Smith, 2011). Wilson's views of his denomination in the omnipotence of God, the morality in the universe, and the reward and punishments system (Link, 1956) has brought the US president to spread the values to its foreign policy which is based on idealism.

For a great number of international relations scholars, constructivism is considered as a claim of significant aspects of international relations. It is considered as significant because it is historically and socially constructed. The constructivism case is rather than inevitable consequences of human nature or characteristics of international politics (Jackson \& Nexon, 2002). On the same hand, for Houghton, "the most logical base" from which Foreign Policy can be approached and on which it can feed and rebuild itself is provided by "social constructivism" that has a significant bearing particularly upon "the cognitive psychological approach to the study of foreign policy (Houghton, 2007)

There are actually deferences between constructivist and foreign policy examinations of foreign policy, one can point to the level inquiry that is mainly considered as micro in foreign policy analysis, concerning policy-makers. (Checkel, 2008) 


\section{DISCUSSION}

\section{Indonesian Foreign Policy}

Indonesian foreign policy actually can be seen from three different theories if it is analyzed from the beginning of Indonesian independence up to current condition. the realism perspective is actually far a way to be implemented in its foreign policy. However, several domestically condition in Indonesia and what had been done by the first Indonesian president, Soekarno can be considered as foreign policy based on realism perspective. One of these was Indonesia Malaysian Confrontation. It was a violent conflict from 1963 to 1966. The confrontation or the conflict stemmed from Indonesia's opposition to the creation of Malaysia (Dennis \& Grey, 1996). In addition, 30 September Communist Movement in 1965 was also kind of realism as it impact on Chinese government which was asking its 30,000 citizens to back to China soon after the movement in 30 September (Roosa, 2015).

On the other hand, Indonesian foreign policy can also be seen from idealism perspective. Indonesian role in organizing Bandung Conference in 1955 is considered as Indonesian foreign policy based on idealism perspective. Furthermore, Indonesian role in the establishment of ASEAN can be considered as one of Indonesian Foreign Policy based on idealism perspective. It is because Indonesia want to have a regional stability and prespority in the regions.

Nevertheless, some of Indonesian foreign policy can be considered as foreign policy based on construtuvism. Indonesia plays an important role international arena, especially in non-traditional security issues such as environmental issue. This Nontraditional issues in international or regional level are shaped by constructivism perspective. That is why, Indonesia Foreign Policy in this term can be considered as constructivism perspective. The more constructivism practices from Indonesian foreign policy can be seen from Middle Power Diplomacy which is implemented by Indonesia.

Eventhough Indonesian foreign policy can be considered by three different theories. It is believed that Indonesian foreign policy is more likely a constructivism based policy. If it can be throw back that Indonesian foreign policy since the beginning of Indonesian independence is Free and Active. This free and active concept is resulting a number of foreign policy which construct and made Indonesia as free country but still active in international arena. It is more explained in the next sub section.

\section{Indonesian Foreign Policy: Free and Active}

Free and Active concept has been introduced since Indonesian Independence in 1945. This concept was introduced by Indonesian first vice president, Mohammad Hatta. The article with a strong concept of Free and Active foreign policy for 
Indonesia was written by Mohammad Hatta and published in Foreign Affairs or currently known as Council on Foreign Affairs. The Idea come as Hatta felt that Indonesia was still struggling with their freedom even after the country declared its independence. However, the desire to enhance social justice and prosperity for Indonesian citizens had encourage the national leader to design foreign policy which can make the country sustain in the cold war period. There were actually five fundamentals which were driving Indonesian foreign policy at the moment to be Free and Active.

First of all, it is to defend the freedom of Indonesian citizen and protect the country itself. The meaning of this first fundamental is really deep for its country as a new independent country. Indonesian founding fathers realized that the freedom of Indonesian citizen is fundamental to get the independence and even to sustain its independence. Secondly, it is to obtain get standard of living such as get enough food, particularly rice, consumer goods, medicines, and other things like that. Thirdly, it is to obtain capital equipment in order to reconstruct the things that had been destroyed. This is to rebuild the industry, new construction, and the partial mechanization of agriculture. Fourthly, this

This is to make the principles of international law much stronger and to get aid in achieving social justice in international level. This is completely in line with the charter of the United Nations which has the framework to help citizens to still live and get freedom from colonial system. Last but not least, it is to place particular emphasis especially to initiate better relation with neighborhood countries. (Hatta, 1953).

Indonesian national leaders felt that Indonesians are jealous with their country itself. It was because the slogan of liberty, humanity, the brotherhood of the nation, and lasting peace were note really implemented after the country got independence. It was realized that Indonesia still got military force from the colony after independence.

Furthermore, Indonesian people realized that they and their country needed to play a role in international level due to the condition in Indonesia. Indonesian people did not want that other countries felt the same thing as Indonesian people suffered. All the feelings finally determined the pattern of Indonesian foreign policy. Nevertheless, Indonesia was really fragile from colonials and block states. Due to the cold war after World War 2, Indonesia was really easy to be influenced without the commitment to be independent in its early independence.

With these five fundamentals and the feelings of Indonesian people at the moment, it can be really clear that the meaning of free and active in Indonesian foreign policy can be defined to be in a neutral position while still active in international arena. Therefore, Indonesia played a role in international arena during cold war period. Interestingly, Indonesia did not affiliate with other block countries. Indonesia 
promoted the independence and encourage colonialized stated to get its independence. Indonesia established non-block alignment which commonly known as Bandung Conference. This is a prove that Indonesia played role in international arena as a point active but Indonesia still free from the dictate of block states.

All in all, Indonesian foreign policy as Free and Active can be understood as Indonesian role in international level could be reached while the country was still free from the dictate or influence of either of West or East Block during the cold war. This Free and Active concept of foreign policy is still implemented up to now. This is completely becoming the roots of Indonesian foreign policy. This can be seen from a current Indonesian foreign policy in current world which is more explained in the next sub tittle in this article. One of the example is the activeness of Indonesia in helping Palestine to get its independence from Israel.

\section{Current Indonesian Foreign Policy}

The current Indonesian foreign policy is strongly influenced by the vision and mission of the current Indonesian president, Joko Widodo (Jokowi). Under Joko Widodo's administration, Indonesian foreign policy is mainly focused on polices based on Nawa Cita. Nawa Cita is a traditional Indonesian language which means nine agendas. There are nine agendas under Jokowi's administration which constructs current Indonesian foreign policy.

First of all, it is romoting Indonesia's identity as an archipelagic state. It can be seen from maritime based concept called Global Maritime Fulcrum. After Djuanda Declaration of 1957, Indonesia got more sovereignty in maritime territorial. Now, Indonesian foreign policy is more likely to expand its maritime to be global maritime fulcrum to accelerate maritime in economic development and international trade. (Chen, J., Gleason, A., Dr. Nabbs-Keller, G., Sambhi, N., Springer, K., Dr. Tanu, 2014).

Secondly, Indonesian foreign policy under Jokowi's administration can be rooted from middle power concept. It enhance middle power diplomacy to play a role in global arena. That is why, Indonesia in the last several years play an important role in multilateral or international forums and organizations such as G20, United Nations, and ASEAN. Moreover, Indonesia also plays a role in bilateral relations especially in Southeast Asian Regions to promote nontraditional issues such as human rights and environmental.

Thirdly, Indonesia is expanding closer relations to Indo-Pacific regions. This agenda is also a part of middle power diplomacy planed by Jokowi's administration in Indonesian foreign policy. Indonesian government is strengthening the regional power and relations especially in the East Asia by joining a number of summits and forums. The goal is to prevent the hegemony of major powers and manage the impact 
of collaborative economic network such as trade and business in the region (Chen, J., Gleason, A., Dr. Nabbs-Keller, G., Sambhi, N., Springer, K., Dr. Tanu, 2014).

Fourthly, economic diplomacy is a part of the agenda to design current Indonesian foreign policy. Moreover, current Indonesian foreign policy can be seen from Indonesian objective to increase defense budget from 0.8 percent to 1.5 percent of the GDP. It means that the budget indicate an effort to reallocate the existing resources more wisely (Connelly, 2014).

Additionally, Indonesian foreign policy can be seen from agenda designed bellow, this was designed under Susilo Bambang Yudhoyono era, and it is finished under Jokowi's administration. The current Indonesian foreign policy agendas are:

A. Indonesia commits to make Indonesian identity as archipelagic country:

- By engaging maritime diplomacy to countries which have seas or similar maritime policy.

- To make sure the sovereignty of Indonesian territory in the sea

- By making a good security protection in Exclusive Economic Zones (EZZ)

- Enhance defense diplomacy (Aritonang, Margareth S., Witular, 2014).

B. Increasing an important role in global arena through middle-power diplomacy:

- By developing the capacity to make sure the safety of diaspora

- By making Indonesian migrant workers as priority to get a full protection

- By increasing promotion in multilateral cooperation and agreement in the United National and regional organizations

- By joining in peace and conflict resolutions agenda (Aritonang, Margareth S., Witular, 2014).

C. Expand engagement in the Indo-Pacific region, which covers countries along the Indian Ocean and the Pacific Ocean:

- Consolidate leadership in ASEAN.

- Strengthen ASEAN cooperation.

- Strengthen regional architecture, particularly of the East Asia Summit.

- Push for regional maritime cooperation, particularly through the Indian Ocean Rim Association. (Aritonang, Margareth S., Witular, 2014)

D. Encourage public participation in formulating and designing foreign policies

- By recognizing the foreign ministry with media mainstream in Indonesia

- By promoting special diplomat to encourage public society (Aritonang, Margareth S., Witular, 2014).

E. Increasing the budget of defense and security:

- By allocating 1.5 percent of GDP

- By Reudcing imports by developing industry

- By developing the Navy into a necessary regional force 


\section{F. Set up National Security Council:}

- By improving the discipline of the police force

- Empowering National Police Commission to be watchdog over policy itself.

- Separating police authorities (Aritonang, Margareth S., Witular, 2014).

\section{Media, Society, and Foreign Policy in Indonesia}

For democratic countries, Media is playing a key role in everyday life such as politics, social, governments and so forth. It is because media tells everything happening in the country and influence the perspective of the citizens. Therefore, there is no doubt that media is somehow shaping public policy and foreign policy in democratic country.

Indonesia was not really democratic and the media was strictly controlled by the government in New Order Period (1966 - 1998). However, since Indonesian reformation in 1998, Indonesia has been more democratic and the media has been becoming really open to inform everything happening in the country. Like getting an independence, media in Indonesia made news without any restriction, limitation, and reluctance. As a result, media has always been making news based on their angles and perspectives. This is shaping people opinion on some issues. Agenda setting in Indonesia has been always used in shaping people perspective in Indonesia.

Media in Indonesia is now becoming much more democratic. Media war in Indonesia sometime happened due to conflict interest. Furthermore, the popularity of social media in Indonesia has been resulting Media in Indonesia becoming more powerful to shape the perspectives of citizens. This is, of course, impact on the process of policy making in Indonesia, not only for domestic policy but also for foreign policy.

Indonesian foreign policy is strongly related to media and public opinion even though it cannot be a benchmark for Indonesian foreign policy somehow. The table shown below is a concept made by Author to figure out the relation of Media Coverage, Public Opinion and Foreign Policy. 


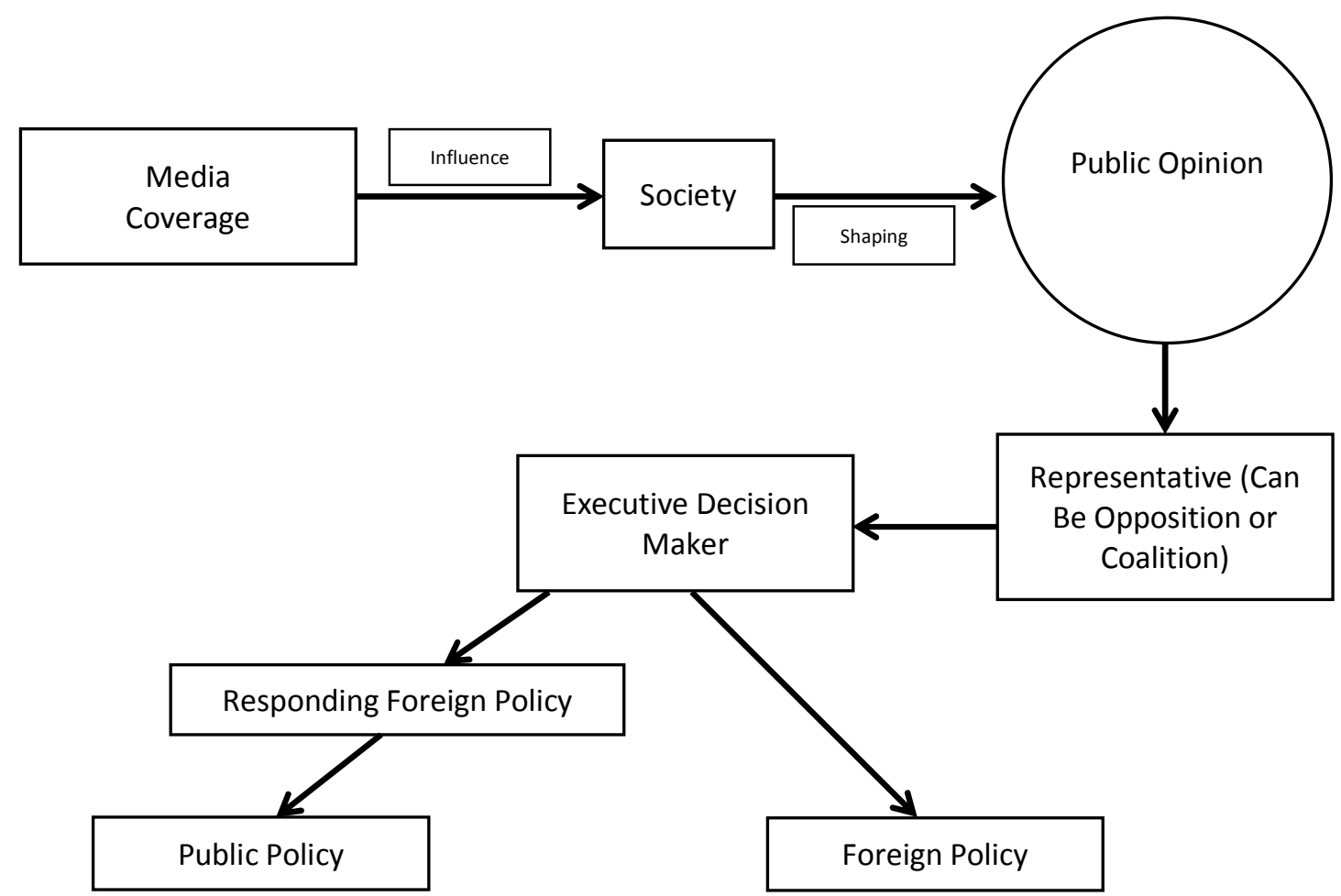

It can be seen that Media coverage in Indonesia is really influential factor in shaping Indonesian policy. It can be domestic policy to respond foreign policy from other countries or Indonesian foreign policy itself. It can be seen from the graph shown, the media coverage or known as agenda setting will influence the perspective of society. If the perspective of the society has been shaped due to media coverage, the society will shape public opinion. This case can be seen from how Indonesia mainstream media shape the perception of China's investment in Indonesia. The media has succeed shaping the perspective and see a China's investment as China's desire to influence communism idea in Indonesia, like what happened in 1960's. As a result, public sees China's investment negatively.

When public opinion has been shaped, it is more likely to be responded by the representative, it can be Coalition of the regime or the opposition. The representative who are legislative will draft policy based on aspiration they got from their constituents. Then, the draft will be purposed to the executive to be implemented and it can be public pol icy as a respond for foreign policy from other countries or foreign policy itself. Another example can be seen from Rohingya case. When society asked Indonesian representative to push the executive to do something in 
order to Myanmar conflict, Indonesian executive responded with several foreign policy such as humanitarian aid, and economic.

\section{CONCLUSION}

Indonesian foreign policy in practices and theories is basically influenced by its historical condition and the world order at the moment of Indonesian independent and afterward. Before the Independence, Indonesian was a place of competition for Japan and Netherland. Thus, this impact on Indonesian views on its foreign policy. This leads Indonesia to have its foreign policy with the concept of Free and Active. This means that Indonesian is free from West and East block which was really strong in the cold war period. However, Indonesia also wanted to be active in international level by organizing Bandung Conference and joining international forum to strengthen Indonesian legacy. "Active" in the concept of Indonesian foreign policy also brings Indonesia to be actively supporting other countries which have not got the independence yet.

Apparently, Indonesian foreign policy with the concept of Free and Active has brought current Indonesian foreign policy to be in a middle power diplomacy. Indonesia is now actively palaying a role in international arena such as active in global forum such as G20 and multilateral cooperation such as ASEAN. Indonesia also advocates nontraditional issues such as environmental, and human right issues in several countries. Moreover, Indonesia also plays an important role in helping Palestine to get its independence from Israel.

In Addition, Indonesian foreign policy has also considered and shaped by public opinion. Thus, the relations between public opinion and media is completely strong in order to shape Indonesian foreign policy in today's world.

To conclude, Indonesian foreign policy is rooted from historical view and condition at the beginning of Indonesian independence and the condition of world system at the time. Indonesian foreign policy can be analyzed by three different theories although the basic theory which is really match with Indonesian foreign policy since its independence is constructivism. However, more literature review need to be conducted in order to get more understanding on how to analyze Indonesian foreign policy especially in theories and practices.

\section{BIBLIOGRAPHY}

Aritonang, Margareth S., Witular, R. A. (2014). Jokowi-Kalla hawkish on economic policies. The Jakarta Post. Retrieved from http://www.thejakartapost.com/news/2014/05/21/jokowi-kalla-hawkisheconomicpolicies.html 
Checkel, J. T. (2008). Constructivism and Foreign Policy. In A. H. and T. D. Steve Smith (Ed.), Foreign Policy: Theories. Actors. Cases (p. 73). Oxford University Press.

Chen, J., Gleason, A., Dr. Nabbs-Keller, G., Sambhi, N., Springer, K., Dr. Tanu, N. (2014). New perspectives on Indonesia: understanding Australia's closest Asian neighbour. Retrieved

from http://perthusasia.edu.au/usac/assets/media/docs/publications/E-Book_NewPerspectiveson-Indonesia_Understanding-Australias-Closest-Neighbour.pdf

Connelly, A. L. (2014). Indonesian foreign policy under President Jokowi, (October).

Dennis, P., \& Grey, J. (1996). Emergency and Confrontation: Australian Military Operations in Malaya and Borneo 1950-1966. St Leonards: Allen and Unwin.

Hatta, M. (1953). Indonesia’s Foreign Policy Mohammad Hatta, 31(3), 441-452.

Houghton, D. (2007). Reinvigorating the Study of Foreign Policy Decision Making: Toward a Constructivist Approach. Foreign Policy Analysis, 3(1), 24.

Jackson, P. T., \& Nexon, D. (2002). Whence Causal Mechanisms? A Comment on Legro. Dilogue IO, 1(1), 81-102. https://doi.org/10.1017/S7777777702000079

Link, A. S. (1956). A Portrait of Wilson. Virginia Quarterly Review, 32(4), 524-541.

Policy, P. F. (2009). Realism.

Reus-Smit, C. (1999). Theories of International Relations.

Reus-Smit, C. (2005). Constructivism. In S. B. and Others (Ed.), Theories of International Relations (p. 199). Basingstoke: : Palgrave.

Roosa, J. (2015). The 1965-66 Politicide in Indonesia: Toward Knowing Who Did What to Whom and Why. Retrieved from http://aparc.fsi.stanford.edu/southeastasia/events/1965-66-politicide-indonesiatoward-knowing-who-did-what-whom-and-why

Smith, H. (2011). Idealist Versus Realist Foreign Policy. University of North Carolina at Chapel Hill, AmericanDiplomacy.org, 18-21.

Wendt, A. (1992). Anarchy is What States Make of It: The Social Construction of Power Politics. International Organization, 46(2).

Wendt, A. (1994). Collective Identity Formation and the International State. American Political Science Review, 88.

Wendt, A. (1999). Social Theory of International Politics. Cambridge: Cambridge University Press. 